\title{
Monitoring the phenology of Myrcianthes pungens (O. Berg) D. Legrand in the state of Rio Grande do Sul - Brazil
}

\author{
Pedro Augusto Veit ${ }^{1}$, Sergio Francisco Schwarz ${ }^{2}$, Divanilde Guerra ${ }^{3}$
}

Abstract - Guabiju (Mycianthes pungens (O. Berg) Legrand) is a fruit tree with great potential for commercial exploitation due to its nutritional characteristics. The aim of this work was to study the reproductive cycle of $M$. pungens in different regions of Rio Grande do Sul. Phenology was monitored from September 2014 to February 2015 in the municipalities of Três Passos (Northwestern region), Parai and Guabiju (Northeastern region), and Porto Alegre (Metropolitan region). As results, variations in reproductive cycle and thermal sum among accessions were observed, and in Três Passos, the reproductive cycle had duration of 95 days and reached thermal sum of $1290^{\circ} \mathrm{C}$. In the municipality of Guabiju, the reproductive cycle lasted 147 days and the thermal sum was $1603^{\circ} \mathrm{C}$. In the municipality of Porto Alegre, the reproductive cycle had duration of 133 days and the thermal sum reached $1564^{\circ} \mathrm{C}$.

Index terms: Guabiju, flowering, fruiting.

\section{Monitoramento da fenologia de Myrcianthes pungens (O. Berg) D. Legrand no estado do Rio Grande do Sul}

Corresponding author: schwarz@ufrgs.br

Received: December 14, 2018 Accepted: January 31, 2019

Copyright: All the contents of this journal, except where otherwise noted, is licensed under a Creative Commons Attribution License.
Resumo - O guabijuzeiro (Mycianthes pungens (O. Berg) Legrand) é uma frutífera que apresenta grande potencial para exploração comercial de seus frutos devido às suas características nutricionais. O objetivo deste trabalho foi estudar o ciclo reprodutivo de $M$. pungens, entre os anos de 2014 e 2015, em distintas regiões do Rio Grande do Sul: acessos de guabijuzeiros dos municípios de Três Passos (região noroeste), Paraí e Guabiju (região nordeste) e Porto Alegre (região Metropolitana). Como resultados, observaram-se variação na fenologia e soma térmica entre os acessos, sendo que, em Três Passos, o ciclo reprodutivo teve duração de 95 dias e atingiu soma térmica de $1.290{ }^{\circ} \mathrm{C}$. No município de Guabiju, o ciclo reprodutivo teve duração de 147 dias, e a soma térmica foi de $1.603{ }^{\circ} \mathrm{C}$. No município de Porto Alegre, o ciclo reprodutivo foi de 133 dias, e a soma térmica, de $1.564^{\circ} \mathrm{C}$.

Termos para indexação: Guabijuzeiro, florescimento, frutificação. 
Brazil has great diversity of native flora, with many fruit species with potential to be economically exploited, which has been attracting the attention of researchers, as well as of food and pharmaceutical industries (SARMENTO et al., 2012). In the southern region of the country, among the many existing native species, fruit trees belonging to the Myrtaceae family stand out due to their great ecological and commercial potential. Among them, guabiju tree (Myrcianthes punges (Berg) Lerg.) stands out, presenting fruits with good acceptance for fresh consumption, which can also be used in the manufacture of processed products (MATTOS, 1989).

Phenological studies contribute to increase the understanding of the ecological relationships of the species. The phenological characterization through the stages of phenophases (vegetative and reproductive) allows obtaining greater description of the plant cycle, providing data to establish the period in which resources such as fruits, seeds, leaves and flowers are available (ALENCAR et al., 1979; BARBOSA et al., 2009). The knowledge of the phenological patterns is considered fundamental for the understanding of the reproductive biology of the species and for the development of breeding programs (MAÚES; COUTURIER, 2002). Therefore, agronomic applications of phenology are broad, highlighting their use in the determination of ecoclimatic requirements, in agricultural zoning and crop management (BERGAMASCHI, 2007).

The reproductive phenology of $M$. punges specimens was monitored from September 2014 to February 2015 in three distinct regions of Rio Grande do Sul. In the municipalities of Três Passos (Northwestern region) ( $27^{\circ} \mathrm{S} 27^{\prime} 31,14^{\prime \prime}$ and $\left.53^{\circ} \mathrm{W} 56^{\prime} 13.64^{\prime \prime}\right)$, Paraí (28 ${ }^{\circ} \mathrm{S} 34^{\prime} 46.2^{\prime \prime}$ and $\left.51^{\circ} \mathrm{W} 47^{\prime} 21.9^{\prime \prime}\right)$ and Guabiju (Northeastern region) ( $28^{\circ} \mathrm{S} 32^{\prime}$ and $\left.51^{\circ} \mathrm{W} 41^{\prime} 27.7^{\prime \prime}\right)$ and Porto Alegre (Metropolitan region) (30 ${ }^{\circ}$ S 04' 19.3" and $51^{\circ} \mathrm{W} 08$ ' $15.8^{\prime \prime}$ ), and one plant was evaluated (aged 15-20 years) per municipality, of which, exsicates were registered at the Herbarium of the Institute of Biosciences of UFRGS: Três Passos (ICN No. 179952), Paraí (ICN No. 179958), Guabiju (ICN No. 175152) and Porto Alegre (ICN No.175139).

The methodology used for the phenological evaluation of guabiju tree was carried out in a direct and qualitative way through analysis of the periods in which flowering and fruiting phenophases occurred (D'EÇA NEVES; MORELLATO, 2004). In the flowering phenophase, the following parameters were analyzed: $1^{\text {st }}$ floral buds, $1^{\text {st }}$ open flower and full bloom (more than $50 \%$ of open flowers); in the fruiting phenophase: fruits at the beginning of maturation (color change) and full maturation (fruit with dark color). Observations were weekly performed until the identification of the beginning of the flowering / fruiting phenophase, while in the other phases of each phenophase, observations were performed every three days.
Climatic data regarding the minimum and maximum temperature of municipalities where the study was performed were provided by the National Institute of Meteorology (INMET) through data collected in the following meteorological stations: Santo Augusto Station (A805) - Latitude: -27.854345 ${ }^{\circ}$; Longitude: -53.791179 '; altitude: 490 meters a.s.l. Passo Fundo Station (A839) Latitude: $-28.226805^{\circ}$; Longitude: $-52.403582^{\circ}$; altitude: 681 meters a.s.l. Porto Alegre Station (A801) - Latitude: $-30.053536^{\circ}$; Longitude: $-51.174766^{\circ}$; altitude: 41 meters a.s.l. The cumulative thermal sum from flowering until fruit maturation was calculated by the method of Arnold (1959):

$\mathrm{ST}=[(\mathrm{TM}+\mathrm{Tm}) / 2]-\mathrm{Tb}$, where: $\mathrm{ST}=$ Thermal sum $\left({ }^{\circ} \mathrm{C}\right) ; \mathrm{TM}=$ daily mean maximum temperature $\left({ }^{\circ} \mathrm{C}\right) ; \mathrm{Tm}=$ daily mean minimum temperature $\left({ }^{\circ} \mathrm{C}\right)$; $\mathrm{Tb}=$ minimum basal temperature for the plant $\left({ }^{\circ} \mathrm{C}\right)$.

For the thermal sum calculation, minimum basal temperature of $10^{\circ} \mathrm{C}$ was adopted, according to Lamarca et al. (2011) and Cunha et al. (2016), because according to the authors, below this temperature, plants of the Myrtaceae family remain in latency state.

The results obtained in this study have shown that there was variation in duration and period of occurrence of reproductive phenophases of guabiju tree in the three regions of the state of Rio Grande do Sul. In the municipality of Três Passos (Northwestern region), flowering occurred in September with duration of 23 days, and the first flower buds appeared on 09/08/2014 and full bloom occurred on 09/30/2014. In Porto Alegre (Metropolitan region), flowering occurred in September and October with duration of 35 days, with the first flower buds appearing on 09/09/2014 and full bloom on 10/14/2014; in the municipalities of Paraí and Guabiju (Northeastern region), flowering occurred between September and November, with an average duration of 40 days, and the first floral buds appeared on 09/15/2014 in Paraí and 09/29/2014 in Guabiju and full bloom occurred on 10/28/2014 in Paraí and 11/06/2014 in Guabiju.

The development of fruits occurred from the beginning of October until the end of November in Três Passos with duration of 61 days (10/01/2014 to $11 / 31 / 2014)$; in Porto Alegre, it occurred from the middle of October to the first week of January, with duration of 86 days (10/15/2014 to 01/06/2015); in Paraí, it began in the end of October (10/29/2014) and lasted until the second half of January (01/22/2015), with duration of 88 days and in Guabiju, it occurred from the beginning of November until the beginning of February, with duration of 93 days (11/07/2014 to 02/06/2015).

Fruit maturation occurred in early December in Três Passos, with duration of 11 days (12/01 to 12/11/2014). In Porto Alegre, it occurred in January, with duration of 12 days (01/07 to 01/19/2015), while in Paraí, it occurred between January and February, with duration of 15 days $(01 / 23$ to $02 / 07 / 2015)$ and in Guabiju, it occurred in 
February, with duration of 15 days (02/07 to 02/22/2015). In this work, a variation of 52 days in the duration of the reproductive cycle was observed, that is, from flowering to fruit maturation in plants from municipalities of Três Passos and Guabiju, with duration of 95 and 147 days, respectively. For plant from the municipality of Porto Alegre, the duration of the reproductive cycle was 133 days.

These results indicate that there is variation in the maturation phase of fruits and in the reproductive cycle duration according to the region where the plant is located. These differences among cycles in the different regions may be associated with the different climatic conditions and accumulated thermal sum (STA), since the municipality of Três Passos (Northwestern region) presented mean monthly minimum and maximum temperatures $\left(15.8\right.$ and $31.8^{\circ} \mathrm{C}$, respectively) higher than those observed in the municipalities of Paraí and Guabiju (Northeastern region) (12.6 and $27.1{ }^{\circ} \mathrm{C}$, respectively), which could be possibly influencing the vegetative development of plants and thus reducing their cycle. Plant grown in Porto Alegre showed intermediate cycle duration when compared to plants grown in Três Passos and Parai / Guabiju, and both temperature (mean minimum and maximum, 13.1 and $30.2^{\circ} \mathrm{C}$, respectively), and STA at this site were intermediate, compared to the other regions.

Similar results were found by Bardin-Camparotto et al. (2012), who evaluated the maturation time for different coffee cultivars (Coffea arabica) in the state of São Paulo. Regions with lower temperatures and higher altitude presented longer cycle duration (period between flowering and full maturation), while in regions with higher temperatures, cycle was shorter and harvest anticipated. Stenzel et al. (2006) observed variation in cycle duration and accumulated degree-days in 'Folha Murcha' orange trees (Citrus sinensis), when conducted in two different locations in the state of Paraná; in the municipality of Londrina, the cycle from anthesis until fruit maturation was 513 days and 5090 accumulated degree-days, and in the municipality of Paranavaí, the cycle was 434 days and 4799 accumulated degree-days.

Três Passos also showed the highest monthly STA $\left(484^{\circ} \mathrm{C}\right)$ when compared to Paraí / Guabiju $\left(395^{\circ} \mathrm{C}\right)$ and Porto Alegre $\left(476^{\circ} \mathrm{C}\right)$. However, due to the shorter duration of its reproductive cycle, it presented the lowest total STA $\left(1290^{\circ} \mathrm{C}\right)$ from flowering to fruiting when compared to Guabiju $\left(1603^{\circ} \mathrm{C}\right)$ and Porto Alegre $\left(1564^{\circ} \mathrm{C}\right)$. The highest STA in the municipality of Guabiju can be explained by the fact that the reproductive cycle was longer, possibly influenced by the mild temperatures of the region, as previously discussed. In Paraí, also located in the Northeastern region, STA was $1521^{\circ} \mathrm{C}$. This STA difference in relation to Guabiju can be explained by the fruit development duration, which in Paraí was 88 days, accumulating $962^{\circ} \mathrm{C}$ and in Guabiju, it was 94 days, accumulating $1063^{\circ} \mathrm{C}$.
In the present study, STA calculation was performed based on the method proposed by Arnold (1959). According to the author, the higher the mean day temperature, the greater the degree-days accumulation, but an upper limit for this increase is not considered. Another potential method for use in this work would be that proposed by Ometto (1981), because this method considers not only the lower basal temperature, but also the upper basal temperature, so in days with temperature that exceed the upper basal temperature, it is not considered. However, for guabiju tree, the upper basal temperature value has not yet been established and therefore it was not possible to use this method. Considering the above, Renato et al. (2013) studied the influence of these two methods on the corn crop, and according to the equation of Arnold, it took 130 days to reach STA of $1600^{\circ} \mathrm{C}$, whereas with that of Ometto, 138 days, showing that under conditions of maximum temperatures above the upper basal temperature, the equation of Arnold can overestimate the thermal sum of the crop and thus reduce the crop cycle.

According to Donadio et al. (2002), the flowering of guabiju tree under the natural conditions of Southern Brazil occurs between October and November and fruit maturation occurs between January and February. Similar results were found in this work in plants from the municipalities of Paraí, Guabiju and Porto Alegre. However, in Três Passos, flowering occurred in September and fruit maturation in the month of December, being indicative that in hot regions, the crop cycle can be anticipated.

The reproductive phenology duration of guabiju tree observed in this work was long when compared to results obtained by Danner et al. (2010) with other species of the Myrtaceae family, where they verified that the full bloom of wild cherry (Eugenia ivolucrata), uvaia (E. pyriformis) and pitanga trees (E. uniflora) occurred until the third week of September, and fruit maturation from the second half of October until the first half of November.

\section{Acknowledgments}

To CNPq, CAPES and FAPERGS for financial support.

\section{References}

ALENCAR, J.C.; ALMEIDA, R.A.; FERNANDES, N.P. Fenologia de espécies florestais em floresta tropical úmida de terra firme na Amazônia Central. Acta Amazonica, Manaus, v.9, n.1, p.163-198, 1979. 
ARNOLD, C.Y. The determination and significance of the base temperature in a linear heat unit system. Proceedings of the American Society for Horticultural Science, Alexandria, v.74, n.1, p.430-445, 1959.

BARBOSA, J.M.; EISENLOHR, P.V.; RODRIGUES, M.A.; BARBOSA, K.C. Ecologia da dispersão de sementes em florestas tropicais. In: MARTINS, S.V. Ecologia de florestas tropicais do Brasil. Viçosa: Editora UFV, 2009. p.52-73.

BARDIN-CAMPAROTTO, L.; CAMARGO, M.B.P. de; MORAES, J.F.L. de. Época provável de maturação para diferentes cultivares de café arábica para o Estado de São Paulo. Ciência Rural, Santa Maria, v.42, n.4, p.594-599, 2012.

BERGAMASCHI, H. O clima como fator determinante da fenologia das plantas. In: REGO, G.M. et al. Fenologia ferramenta para conservação, melhoramento e manejo de recursos vegetais arbóreos. Colombo: Embrapa Florestas, 2007. p.291-310.

CUNHA, L.L.T.; LUCENA, E.M.P. de; BONILLA, O.H. Exigências térmicas da floração à frutificação de quatro espécies de Myrtaceae em ambiente de restinga. Revista Brasileira de Geografia Física, Recife, v.9, n.3, p.498$512,2016$.

D'EÇA NEVES, F.F.; MORELLATO, L.P.C. Métodos de amostragem e avaliação utilizados em estudos fenológicos de florestas tropicais. Acta Botânica Brasílica, Belo Horizonte, v.18, n1, p.99-108, 2004.

DANNER, M.A.; CITADIN, I.; SASSO, S.A.Z.; SACHET, M.R.; AMBRÓSIO, R. Fenologia da floração e frutificação de mirtáceas nativas da floresta com araucária. Revista Brasileira de Fruticultura, Jaboticabal, v.32, n.1, p.291-295, 2010.
DONADIO, L.C.; MÔRO, F.V.; SERVIDONE, A.A. Frutas brasileiras. Jaboticabal: Funep, 2002. 288p.

LAMARCA, E.V.; SILVA, C.V.; BARBEDO, C.J. Limites térmicos para germinação em função da origem de sementes de espécies de Eugenia (Myrtaceae) nativas do Brasil. Acta Botanica Brasilica, Belo Horizonte, v.25, n.2, p.293-330, 2011.

MATTOS, J.R. Myrtaceae do Rio Grande do Sul. Porto Alegre: CEUE, 1989. 721p.

MAUÉS, M.M.; COUTURIER, G. Biologia floral e fenologia reprodutiva do camu-camu (Myrciaria dúbia (H. B. K.) Mc Vaugh, Myrtaceae) no Estado do Pará, Brasil. Revista Brasileira de Botânica, São Paulo, v.25, n.4, 2002.

OMETTO, J.C. Bioclimatologia vegetal. São Paulo: Agronômica Ceres, 1981. 440p.

RENATO, N. dos S.; SILVA, J.B.L.; SEDIYAMA, G.C.; PEREIRA, E.G. Influência dos métodos para cálculo de graus-dia em condições de aumento de temperatura para as culturas de milho e feijão. Revista Brasileira de Meteorologia, São José dos Campos, v.28, n.4, p.382388, 2013.

SARMENTO, M.B.; SILVA, A.C.S. da; SILVA, C.S. da. Recursos genéticos de frutas nativas da família Myrtaceae no Sul do Brasil. Magistra, Cruz das Almas, v.24, p.250262, 2012.

STENZEL, N.M.C.; NEVES, C.S.V.J.; MARUR, C.J.; SCHOLZ, M.B. dos S.; GOMES, J.C. Maturation curves and degree-days accumulation for fruits of 'Folha Murcha' Orange trees. Scientia Agricola, Piracicaba, v.63, n.3, p.219-225, 2006. 